\title{
Pengaruh Model Pembelajaran Kooperatif Tipe STAD Berbantuan Media Poster Terhadap Hasil Belajar Peserta Didik
}

\author{
Normasintasari Kusumawardani ${ }^{1 *}$, Joko Siswanto², Veryliana Purnamasari3 \\ ${ }^{123}$ Pendidikan Guru Sekolah Dasar, Fakultas Ilmu Pendidikan, Universitas PGRI Semarang
}

\author{
A R T I C L E I N F O \\ Article history: \\ Received 20 February 2018 \\ Received in revised form \\ 6 March 2018 \\ Accepted 20 April 2018 \\ Available online 26 May \\ 2018 \\ Kata Kunci: \\ Model Kooperatif tipe STAD \\ Media Poster, Hasil Belajar \\ Keywords: \\ STAD type cooperative \\ model, poster media, results \\ Learn.
}

\begin{abstract}
A B S T R A K
Penelitian ini bertujuan mengetahui seberapa besar pengaruh model pembelajaran kooperatif tipe STAD berbantu media poster terhadap hasil belajar peserta didik kelas V SD Negeri Penanggulan Kendal, mengetahui seberapa besar pengaruh model pembelajaran kooperatif tipe STAD berbantu media poster terhadap hasil belajar peserta didik kelas V SD Negeri Penanggulan Kendal. Desain penelitian ini adalah penelitian Eksperimen dengan desain Intact-Group Comparison. Hasil penelitian menunjukan adanya peningkatan hasil belajar siswa yang dapat dilihat berdasarkan hasil pretest dan posttest, kontrol dan eksperimen yang sudah dilakukan. Hal tersebut telah dibuktikan dalam pengujian hipotesis, yang menyatakan bahwa nilai $t_{\text {hitung }}$ lebih kecil dari $t_{\text {tabel }}$ pada nilai $(1,74<4,28)$ yang artinya $\mathrm{H} 0$ diterima dan $\mathrm{Ha}$ ditolak. Perhitungan tersebut menunjukan bahwa terdapat perbedaan pada hasil belajar siswa setelah menggunakan media poster pada model kooperatif tipe STAD dalam kegiatan belajar mengajar yang telah dilakukan. Sehingga dapat disimpulkan bahwa pembelajaran dengan menggunakan media poster pada model kooperatif tipe STAD efektif terhadap hasil belajar matematika siswa.
\end{abstract}

\section{A B S T R A C T}

This study aims to find out how much influence the cooperative learning model of the posterassisted STAD type media on the learning outcomes of fifth grade students of SD Negeri Penanggulan Kendal, knowing how much influence the poster-assisted STAD cooperative learning model on the learning outcomes of grade V students of SD Negeri Penanggulan Kendal. Design of the Experimental research method. Design of Intact-Group Comparison. The results showed an increase in student learning outcomes that can be seen based on the results of the pretest and posttest, controls and experiments that have been done.. It was proven in testing the hypothesis, which states that the value of $t_{\text {hitung }}$ count smaller than $t_{\text {tabel }}$ at value $(1.74<4.28)$ which means $\mathrm{HO}$ is accepted and $\mathrm{Ha}$ is rejected. The calculation shows that there are differences in student learning outcomes after using poster media on the STAD type cooperative model in the teaching and learning activities that have been carried out. So it can be concluded that learning using the poster media on the STAD type cooperative model is effective against students' mathematics learning outcomes. 


\section{Pendahuluan}

Pembelajaran adalah "suatu kombinasi yang tersusun meliputi unsur-unsur manusiawi, material fasilitas, perlengkapan dan prosedur yang saling mempengaruhi tercapainya tujuan pembelajaran" (Oemar Hamalik, 2006 : 239). Sejalan dengan hal tersebut, maka guru harus mampu menarik perhatian serta membuat peserta didik berpartisipasi aktif selama proses pembelajaran. Guru juga harus mampu memilih strategi pembelajaran yang tepat agar memudahkan peserta didik dalam memahami serta menguasai materi pelajaran. Strategi pembelajaran dalam hal ini adalah penguasaan guru mengenai model, metode, serta media pembelajaran. Dengan demikian, guru dituntut untuk kreatif dan inovatif dalam menyampaikan materi pelajaran kepada peserta didik agar pembelajaran menjadi aktif dan tidak membosankan. Salah satu cara yang dapat dilakukan oleh guru agar peserta didik aktif dalam pembelajaran yaitu dengan menggunakan media maupun model pembelajaran yang menarik agar peserta didik merasa antusias, aktif, serta memahami maupun menguasai materi pelajaran.

Pada kenyataannya, kondisi di SD N Penanggulan masih banyak guru yang tidak selalu menggunakan media pembelajaran, keterbatasan media pembelajaran sangat mempengaruhi serta metode maupun model pembelajaran yang cenderung sama setiap kali mengajar di kelas. Kondisi seperti ini membuat peserta didik merasa bosan serta kurangnya minatbelajar dan keaktifan peserta didik dalam proses pembelajaran.Hal tersebut mengakibatkan pada hasil belajar peserta didik yang kurang optimal.Keberhasilan dalam kegiatan pembelajaran di sekolah tidak hanya ditentukan oleh ketepatan strategi guru dalam mentransfer pengetahuannya, tetapi juga ditentukan oleh peran serta aktif dari peserta didik dalam proses pembelajaran.Dengan demikian, guru harus mengupayakan pembelajaran yang menyenangkan supaya dapat menarik perhatian peserta didik.

Berdasarkan pengamatan yang dilakukan peneliti di SD N Penanggulan Kendal pada Senin, 18 Juni 2018 melalui wawancara terhadap salah satu guru/wali kelas V SD N Penanggulan, bahwa terdapat masalah yang timbul akibat berkaitan dengan pembelajaran pada kelas V, yakni keaktifan siswa kurang serta pemahaman siswa pada mata pelajaran bahasa indonesia khususnya pada Kompetensi Dasar (KD) 1.3 Mengidentifikasi Fungsi Organ Pencernaan Manusia dan Hubunganya dengan Makanan dan Kesehatan, peneliti juga melihat kurangnya penggunaan media pembelajaran yang digunakan serta metode dan model pembelajaran yang kurang efektif, sehingga pembelajaran hanya berjalan satu arah saja yakni Teacher Centered. Pada kenyataannya guru masih menerapkan metode ceramah dalam pembelajaran dimana siswa hanya sebagai pendengar sehingga kurang melibatkan aktivitas siswa secara langsung. Siswa hanya dianggap sebagai gelas kosong yang harus diisi penuh tanpa memperhatikan pengetahuan yang dibawa siswa. Akan tetapi guru mengaku pernah sesekali menggunakan metode diskusi dalam proses pembelajaran. Mengingat waktu dan target pengajaran materi yang telah ada di sekolah, metode ceramah dianggap sebagai metode yang paling cepat dalam menyelesaikan materi pengajaran. Metode ceramah yang digunakan oleh guru, pembelajaran guru yang kurang variatif, serta kurangnya sarana prasarana sebagai media dalam pembelajaran.

Jenis metode pembelajaran kooperatif mempunyai berbagai model. Namun dari berbagai model pembelajaran kooperatif tersebut yang dirasa paling tepat bagi siswa dalam pembelajaran ditinjau dari kemampuan potensi akademik menurut peneliti adalah Student Team Achievement Division (STAD). Dalam pembelajaran kooperatif model STAD akan memberikan kesempatan kepada siswa untuk berdiskusi dalam kelompok kelas sehingga akan tercipta suasana belajar yang lebih aktif, efektif dan menyenangkan (Primartadi, 2012). Metode STAD adalah untuk memotivasi siswa agar saling membantu dalam memahami sebuah materi pelajaran dan saling membantu dalam menyelesaikan masalah (Utami,2015). Model Pembelajaran Kooperatif tipe Student Team Achievement Division (STAD) yang dikembangkan oleh Robert Slavin dan teman-temannya di Universitas John Hopkin (dalam Slavin, 1995) merupakan pembelajaran kooperatif yang paling sederhana, dan merupakan pembelajaran kooperatif yang cocok digunakan oleh guru yang baru mulai menggunakan pembelajaran kooperatif.

Model pembelajaran kooperatif tipe STAD dikembangkan oleh Slavin dan merupakan salah satu tipe kooperatif yang menekankan pada adanya aktivitas dan interaksi antar anggota kelompok belajar yang terdiri dari 4-6 siswa dengan tingkat kemampuan dan jenis kelamin yang berbeda untuk saling memotivasi dan membantu dalam menguasai materi pelajaran guna mencapai prestasi yang maksimal (Kristi, 2013).

\section{Metode}

Tempat penelitian akan dilaksanakan di SD Negeri Penanggulan Kendal yang berlokasi di Jalan Pegandon-Putat, Desa Penanggulan, Kecamatan Pegandon, Kabupaten Kendal. Alasan peneliti melakukan 
penelitian SD Negeri Penanggulan Kendal karena peneliti menemukan permasalahan berdasarkan kegiatan wawancara dengan guru kelas $\mathrm{V}$ yang sudah peneliti lakukan selama 1 hari.

Waktu penelitian direncanakan akan dilaksanakan pada semester 1 tahun pelajaran 2018/2019 dengan rincian menyusun proposal penelitian, penyusunan instrumen penelitian, persiapan penelitian, melaksanakan penelitian eksperimen, menyusun hasil penelitian, dan penyempurnaan.

Penelitian eksperimen yang peneliti lakukan menggunakan teknik pengumpulan data sebagai berikut: (1) Wawancara (interview) adalah teknik penelitian yang dilaksanakan dengan cara dialog baik secara langsung (tatap muka) mmaupun melalui saluran media tertentu antara pewawancara dengan yang diwawancarai sebagai sumber data (Sanjaya, 2015: 263). Wawancara tersebut dilakukan peneliti ketika melakukan studi pendahuluan untuk menemukan permasalahan yang terjadi di kelas. (2) Sanjaya (2015: 251-252) menyatakan bahwa tes adalah instrumen atau alat untuk mengumpulkan data tentang kemampuan subjek penelitian dengan cara pengukuran. Dalam penelitian pendidikan, tes sering digunakan sebagai alat untuk mengukur kemampuan, baik kemampuan dalam bidang kognitif, afektif, maupun psikomotor.

Peneliti menggunakan teknik tes dalam penelitian untuk mencari data hasil belajar peserta didik pada tes awal (pretest) sebelum diberi perlakuan dan mencari data hasil belajar peserta didik pada tes akhir (posttest) yaitu pada kelas eksperimen yang telah diberi perlakuan (menggunakan media Poster pada pembelajaran kooperatif tipe STAD dengan kelas kontrol yang tidak diberi perlakuan. (3) Teknik dokumentasi ini merupakan teknik yang digunakan peneliti dalam mencari berbagai macam data. Peneliti menggunakan teknik pengumpulan data dokumentasi untuk mengetahui daftar nama peserta didik maupun hasil belajar yang pernah dicapai peserta didik.

\section{Hasil dan Pembahasan}

Media dan model pembelajaran memang wajib untuk guru berikan kepada siswa. Kejenuhan dalam menggunakan model dan metode konvensional dapat diatasi dengan menggunakan model dan metode pembelajaran baru disertai dengan media yang dapat menarik perhatian siswa dalam menerima pembelajaran dikelas, misalnya media sapuan yang dapat menjadikan siswa aktif selama mengikuti pembelajaran dikelas. Terlebih lagi pada pembelajaran IPA, sehingga media dapat mendukung pembelajaran untuk menunjukkan kekonkritannya. Kejenuhan pada siswa dapat dilihat dari hasil belajar yang kurang maksimal masih banyak siswa di SD N 01 Penanggulan yang mendapatkan nilai IPA kurang maksimal dengan Kriteria Ketuntasan Minimal (KKM) sebesar 70. Hal ini dikarenakan guru yang menggunakan model pembelajaran kurang menarik.

Model Kooperatif tipe STAD berbantu media Poster merupakan salah satu alternatif yang membuat siswa terlibat aktif dalam proses pembelajaran, sehingga siswa dapat memiliki pemahaman yang lebih baik khususnya pada mata pelajaran IPA Model Kooperatif tipe STAD berbantu media Poster. Hal ini didukung dari pendapat Huda (2017: 206) mengungkapkan bahwa "Model Kooperatif tipe STAD strategi yang memperkenalkan gagasan tentang waktu tunggu atau berpikir" pada elemen interaksi pembelajaran kooperatif yang saat ini menjadi salah satu faktor ampuh dalam meningkatkan respon siswa terhadap pertanyaan. Untuk itu Peneliti melakukan penelitian di SD Negeri Penanggulan tahun ajaran 2018/2019 pada siswa kelas 5. Dengan kelas eksperimen berjumlah siswa 18 siswa dan kelas kontrol berjumlah 28 siswa. Kedua kelas memiliki kemampuan yang sama, dibuktikan dengan hasil normalitas dan homogenitas. Kelas eksperimen diberikan perlakuan dengan menggunakan Model Kooperatif tipe STAD berbantu media Poster sedangkan kelas kontrol diberikan model konvensional yaitu ceramah.

Berdasarkan hasil analisis uji coba instrumen, dengan mempertimbangkan validitas, reliabilitas, tingkat kesukaran dan daya pembeda maka didapat 30 soal memenuhi kriteria dari 30 soal uji coba instrumen. 30 soal uji coba digunakan untuk pretest dan posttest kelas eksperimen dan kelas kontrol. Uji pretest kelas kontrol didapat rata-rata kelas sebesar 38,05. Dari 18 siswa terdapat 0 siswa yang belum mencapai KKM. Sedangkan kelas eksperimen yang diberikan pembelajaran menggunakan Model Kooperatif tipe STAD berbantu media Poster dari 18 siswa terdapat 5 siswa yang belum mencapai KKM dengan rata-rata kelas sebesar 79,77. Pada analisis perhitungan menggunakan uji t diperoleh thitung = 1,74. Dari daftar distribusi $t$ dengan $\mathrm{dk}=18+28-1=35$ diperoleh 0,275 Karena thitung $>$ ttabel maka H0 ditolak, sehingga dapat disimpulkan bahwa rata-rata hasil belajar kelas eksperimen lebih besar dari kelas kontrol. Hal ini menunjukkan bahwa Model Kooperatif tipe STAD berbantu media Poster efektif untuk menigkatkan hasil belajar matematika kelas 1 SD N 01 Penanggulan. Siswa terlibat aktif selama proses pembelajaran berlangsung. Berdasarkan uraian diatas dapat diketahu bahwa pembelajaran dengan menggunakan Model Kooperatif tipe STAD berbantu media Poster lebih efektif untuk menigkatkan hasil belajar IPA kelas 5 SD N Penanggulan. Hasil penelitian menunjukkan bahwa Model Kooperatif tipe STAD berbantu media Poster membantu guru dalam mengelola kelas selama pembelajaran berlangsung. Hal ini 
dikarenakan siswa lebih tertarik, merasa senang, serta dapat mendukung dan membantu penyerapan siswa aktif selama proses pembelajaran berlangsung. Dari penelitian ini dapat diketahui bahwa kelas eksperimen lebih baik dari kelas kontrol. Hasil belajar adalah kemampuan-kemampuan yang dimiliki siswa setelah siswa menerima pengalaman belajarnya. Sudjana (2012:22).

Hasil penelitian ini didukung dari penelitian yang dilakukan oleh Widiatmoko, Sajidun. (2014). "Pengaruh Model Kooperatif tipe STAD berbantu media Poster Siswa Kelas V SD Negeri Kancilan 04 Jepara". Dari hal tersebut dijelaskan bahwa pembelajaran dengan menggunakan Model Kooperatif tipe STAD berbantu media Poster dapat meningkatkan hasil belajar siswa. Dari perhitungan uji t diperoleh ttabel sebesar 2,021 dan thitungsebesar 2,128. Oleh karena itu thitung $>$ ttabelmaka Ho ditolak dan Ha diterima. Dengan demikian dapat disimpulkan bahwa hipotesis yang mengatakan bahwa ada perbedaan hasil belajar siswa pembelajaran Model Kooperatif tipe STAD berbantu media Poster dengan hasil belajar siswa pembelajaran dengan metode konvensional dapat diterima. Bedasarkan penelitian terdahulu yang dilakukan oleh Widiatmoko, Sajidun. Peneliti melakukan analisis data dari awal sampai akhir penelitian, dapat disimpulkan bahwa Model Kooperatif tipe STAD berbantu media Poster efektif digunakan untuk meningkatkan hasil belajar siswa pada materi IPA kelas 5 Sekolah Dasar.

Rata-rata hasil belajar siswa berdasarkan pada hasil nilai pretest kelas eksperimen yang telah dilakukan diperoleh sebesar 64,88 dan nilai rata-rata berdasarkan hasil postest kelas eksperimen yang telah dilakukan diperoleh sebesar 79,77. Dan rata-rata hasil nilai pretest kelas kontrol yang telah dilakukan diperoleh sebesar 38,0 dan nilai rata-rata berdasarkan hasil postest kelas kontrol diperoleh sebesar 59,94. Jika diubah kedalam bentuk presentase berdasarkan hasil kelas eksperimen jumlah siswa yang mencapai KKM pada hasil ketuntasan belajaryang diperoleh $72,2 \%$ atau sejumlah 13 siswa dari 18 siswa. Sedangkan berdasarkan hasil kelas kontrol jumlah siswa yang mencapai KKM sebesar 33,3\% atau sejumlah 6 siswa dari 18 siswa. Dengan demikian tujuan penelitian telah tercapai dan hasil penelitian menunjukan hasil belajar siswa mengalami peningkatan dan hasil belajar siswa yang memenuhi KKM melebihi $72,2 \%$.

\section{Simpulan dan Saran}

Berdasarkan hasil penelitian maka dapat disimpulkan bahwa Model Kooperatif tipe STAD berbantu media Poster efektif terhadap hasil belajar IPA siswa kelas 5 SD N Penanggulan. Keefektifan tersebut dapat dibuktikan dengan perolehan nilai rata-rata Rata-rata hasil belajar siswa berdasarkan pada hasil nilai pretest kelas eksperimen yang telah dilakukan diperoleh sebesar 64,88 dan nilai rata-rata berdasarkan hasil postest kelas eksperimen yang telah dilakukan diperoleh sebesar 79,77. Dan rata-rata hasil nilai pretest kelas kontrol yang telah dilakukan diperoleh sebesar 38,0 dan nilai rata-rata berdasarkan hasil postest kelas kontrol diperoleh sebesar 59,94, thitung> ttabel maka maka Ho diterima. Jadi dapat disimpulkan bahwa nilai rata-rata hasil belajar siswa menggunakan Model Kooperatif tipe STAD berbantu media Poster lebih baik dan melebihi KKM dari rata-rata hasil belajar siswa yang tidak menggunakan Model Kooperatif tipe STAD berbantu media Poster pada siswa kelas I SD N Penanggulan.

\section{Daftar Rujukan}

Aqib, Zainal. 2014. Model-Model, Media, dan Strategi Pembelajaran Kontekstual (Inovatif). Bandung: Yrama Widya.

Daryanto \& Mulyo Raharjo. 2012. Model Pembelajaran Inovatif. Yogyakarta: Gava Media.

Dewantara, D. (2014). Penerapan Model Pembelajaran Problem Based Learning Untuk Meningkatkan Aktivitas Dan Hasil Belajar Siswa Pada Pelajaran IPA (Studi Pada Siswa Kelas V SDN Pengambangan 6 Banjarmasin). Jurnal Paradigma Volume 11 Nomor 2 Juli 2016, 41 - 44.

Fathurrohman, Muhammad \& Sulistyorini. 2012. Belajar dan Pembelajaran Meningkatkan Mutu Pembelajaran Sesuai Standar Nasional. Yogyakarta: Teras.

Kurniawan, Deni. 2014. Pembelajaran Terpadu Tematik (Teori, Praktik, dan Penilaian). Bandung: Alfabeta.

Kristi, Lela Widya, Ashadi, dan Nanik Dwi Nurhayati. 2013. Studi Komparasi Metode STAD Dan TGT Ditinjau Dari Memori Terhadap Prestasi Belajar Siswa Pada Sub Pokok Bahasan Minyak Bumi Pada Siswa Kelas X SMA N 1 Teras Boyolali Tahun Ajaran 2011/2012. Jurnal Pendidikan Kimia. Vol. 2, No.3. 
Lamda, Hendrik Arung. 2006. Pengaruh Pembelajaran Kooperatif Model STAD Dan Gaya Kognitif Terhadap Hasil Belajar Fisika Siswa SMA. Jurnal Ilmu Pendidikan. Jilid 13, Nomor 2.

Lestari, Nana Dian, Sri Retno Dwi ariani, Ashadi. 2014. Pengaruh Pembelajaran Kimia Menggunakan Metode Student Teams Achievementm Divisions (STAD) Dan Team Assisted Individualization (TAI) Dilengkapi Media Animasi Terhadap Prestasi Belajar Siswa Pada Materi Asam Basa Kelas XI Semester Ganjil Smk Sakti Gemolong Tahun Pelajaran 2013/2014. Jurnal Pendidikan Kimia. Vol. 3, No. 1.

Majid, Abdul. 2014. Pembelajaran Tematik Terpadu. Bandung: PT Remaja Rosdakarya.

Mursyidun Nidhom, Ahmad. 2015. Hubungan Kesiapan Belajar, Lama Pembelajaran, Kesesuaian Tempat Dan Partisipasi Du/Di Dengan Hasil Prakerin Peserta Didik Kompetensi Keahlian Tkj Di Smk Kota Batu. Volume 11, Nomor 1 (hal. 1-14).

Nataliya, Prima. Efektifitas Penggunaan Media Pembelajaran Permainan Tradisional Congklak untuk Meningkatkan Kemampuan Berhitung pada Siswa Sekolah Dasar. Universitas Muhammadiyah

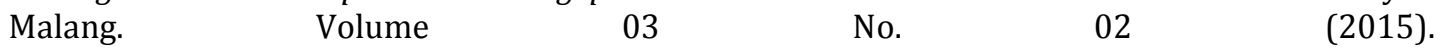
http://ejournal.umm.ac.id/index.php/jipt/article/view/3536/4069, 07 November 2017 pukul 21.44 WIB.

Ningtiyas, Pitria, dan Heri Siswaya. 2012. Penggunaan Metode Kooperatif Tipe TGT Dilengkapi Modul Dan LKS Ditinjau Dari Aktivitas Siswa. Jurnal Penelitian Pembelajaran Fisika. Vol. 3, No. 1.

Primartadi, Aci. 2012. Pengaruh Metode Student Teams-Achievement Division (STAD) Dan Problem Based Learning Terhadap Hasil Belajar Ditinjau Dari Potensi Akademik Siswa SMK Otomotif. Jurnal Pendidikan Vokasi. Vol.2, No.2.

Rusman. 2015. Pembelajaran Tematik Terpadu Teori, Praktik dan Penilaian). Jakarta: PT RajaGrafindo Persada.

Rahmasari, R. (2016). Penerapan Model Pembelajaran Problem Based Learning Untuk Meningkatkan Hasil Belajar IPA Kelas IV SD. Jurnal Pendidikan Guru Sekolah Dasar Edisi 36 Tahun ke 5 2016, 3456 3465 .

Sanjaya, Wina. 2015. Penelitian Pendidikan (Jenis, Metode dan Prosedur). Jakarta: Prenada Media Group.

Suprijono, Agus. 2012. Cooperative Learning Teori dan Aplikasi PAIKEM. Yogyakarta: Pustaka Pelajar

Suwandi, Y. (2015). Peningkatan Hasil Belajar IPA Tentang Ekosistem Melalui Metode Problem Based Learning Pada Siswa Kelas V Sekolah Dasar Kabupaten Tana Tidung. Jurnal Pendidikan Dasar Volume 6 Edisis 1 mei 2015, 93 - 102.

Syafriana, D. (2016). Penerapan Model Problem Based Learning (Pbl) Dalam Pendekatan Saintifik Untuk Meningkatkan Hasil. Jurnal Inovasi Pendidikan Dan Pembelajaran Sekolah Dasar, 30 - 43.

Utami, Santi. 2015. Peningkatan Hasil Belajar Melalui Pembelajaran Kooperatif Tipe STAD Pada Pembelajaran Dasar Sinyal Video. Jurnal Pendidikan Teknologi dan Kejuruan. Vol. 22, No. 4. 